PEREZ, Clotilde. Mascotes Semiótica da vida Imaginária. São Paulo: Cengage Learning. 2010: 144.

\title{
O MUNDO DIVERTIDO DAS MASCOTES LEVADO A SÉRIO
}

Eneus Trindade ${ }^{1}$

Foi com grande satisfação que recebi o convite para resenhar o livro Mascotes Semiótica da vida Imaginária, de autoria da minha ilustre colega de trabalho e amiga Clotilde Perez, lançado no final de 2010 pela editora Cengage Learning.

Ao valorizar a caráter lúdico do tema, a autora demonstra com leveza e consistência, um percurso vigoroso de pesquisa que resultou nesta publicação, desenvolvida dentro do Grupo de Estudos Semióticos em Comunicação, Cultura e Consumo - GESC ${ }^{3} \mathrm{CNPq} / \mathrm{USP}$, que se somou a um estágio de Pós-Doutorado na área de Comunicação, na Universidad de Múrcia-Espanha em 2009 com financiamento da Fundação Carolina-ES.

Essa consistência pode ser percebida desde o início da obra que conta com dois prefácios de pesquisadores internacionais. O primeiro deles, de autoria do Prof. Dr. Pedro Hellín da Universidad de Múrcia, supervisor do estágio de Pós-Doutorado da autora, ressalta a importância dos estudos das mascotes que não comunicam apenas um produto ou uma marca, mas acrescentam à relação marca-consumidor humanidade.

Já o segundo, de autoria do Prof. Dr. Paulo de Lencastre da Universidade Católica Portuguesa - Porto aborda a relevância da obra para o desenvolvimento de reflexões acerca da Gestão das Marcas, por reconhecer que este é um assunto pouco estudado e de grande utilidade aos profissionais gestores, no que concerne aos usos estratégicos das mascotes na comunicação das marcas, considerando que estes encantadores personagens da vida midiática publicitária possibilitam a criação de vínculos emocionais das marcas junto à vida cotidiana dos consumidores de todas as partes do globo.

O livro organizado em quatro capítulos (I - Personagens: uma visão multidisciplinar; II - Mascotes: fetiche contemporâneo; III - Modelo de Criação e

\footnotetext{
${ }^{1}$ Professor da Escola de Comunicações e Artes da Universidade de São Paulo, atuando na graduação em Publicidade e Propaganda e no PPGCOM/USP. Pós-Doutor em Antropologia Visual pela Universidade Aberta - Portugal. Editor da Revista Signos do Consumo.
} 
análise semiótica de mascotes e personagens; IV - Por uma taxionomia de personagens e mascotes), além da introdução e das considerações finais, inclui um curioso "mascotário de marcas", que funciona como um memorável inventário histórico de mascotes que permearam e permeiam as nossas vidas.

A abordagem feita na obra aponta para uma coerência com a trajetória da produção científica da autora, a exemplo do livro Signos da Marca. Expressividade e Sensorialidade, editado em 2004 também pela Cengage Learning, pois o texto faz revelar um amplo estudo reflexivo e taxionômico sobre as mascotes e personagens publicitárias, enquanto manifestações das expressões das marcas.

Ao mergulharmos nos meandros do livro, percebemos no capítulo I o tratamento teórico-conceitual da personagem quanto à etimologia do termo e sua função na literatura, teatro, cinema e televisão, para a construção de identidades de marcas. Isso demonstra o cuidado da autora em situar os estudos da personagem em função dos seus propósitos, considerando a multiplicidade de gêneros e linguagens por onde este objeto se faz pertinente, até chegar à personagem/mascote como expressão identitária das marcas.

Esta parte do texto revela uma competente abordagem que passa por autores significativos do trajeto conceitual realizado, passando por Antonio Candido, Foster, Pallotini, Segolin, Rosenfeld, Bakhitn, Mauriac, Paulo Emílio Gomes, Syd Field entre outros, finalizando com a reflexão sobre a presença e construção das personagens nas suas características psicossociais da cotidianidade e como expressões no mundo digital até chegar à sua manifestação como expressão marcária.

Já o segundo capítulo aborda a etimologia das mascotes e suas origens históricas, mostrando como tais personagens se manifestam e se vinculam à complexa teia da vida cultural, apresentando entre as páginas 43 a 54, uma primeira classificação destes personagens, a saber: a mascote em suas características sígnicas icônicas e hipersígnicas; como ídolos; sua função fetichizante; sua função mediadora entre infância e vida, como manifestação de emblemas da cultura de massas; da sua condição de promover uma onipresença na vida cotidiana. E finalizando esta discussão, a autora apresenta uma inusitada reflexão, bem fundamentada, sobre a mascote na sua manifestação como monstro que possibilita uma conexão profícua entre o fetichismo causado por esse artefato cultural na produção de mitos, fortalecendo nesta perspectiva, a relação entre mito, publicidade e mascotes. Trata-se de uma das partes mais instigantes da obra. 
O capítulo 3 apresenta o modelo de criação de mascotes suportado pela metodologia da análise semiótica de fundamentação peirciana, demonstrando como as mascotes se constituem como fenômeno sígnico e produtoras de sentidos na vida cultural, trazendo um rico inventário de personagens marcárias e que faz jus às reconhecidas competências da autora na aplicação da teoria semiótica às expressões das marcas para as produções de sentido no consumo.

Percebemos que o capítulo anterior gera as condições de potencialidades de sentidos para que autora possa propor no capítulo IV, na semiose de seu processo científico de trabalho, uma valiosa taxionomia de personagens e mascotes. (PEREZ, 2010: 81).

Fora do universo das mascotes a autora propõe a classificação das personalidades que incluem as celebridades, os especialistas/experts e o porta-voz.

No campo da personagem que se configura como uma categoria maior, distinta às personalidades, tem-se um conjunto de manifestações marcárias em tipos humanos, animais, mascotes e licenciamentos. E dentro destas classificações se incluem os humanos (ficcionais midiáticos e gráficos corpóreos e metonímicos). Os animais compreendem uma categoria sem subclassificações (embora seja importante destacar que existem mascotes animais), assim como os licenciamentos, que perpassam todas as categorias de personagens e que dependendo do sucesso e da projeção que a marca queira dar a tal personagem, pode haver a comercialização da imagem deste em uma série de objetos/produtos, conhecidos como spin-offs e outros materiais de promoção.

Já no âmbito das mascotes em si, autora propõe as manifestações classificadas como humanoides, míticas, heróis, monstros, animais, animações (de animais e de pessoas) e a antropomorfização que diz respeito à humanização de algo inanimado (alimentos, fenômenos da natureza, sinais gráficos, objetos).

Cada tipo desta classificação aponta para um certo modo de rentabilidade que permite a construção de vínculos de sentidos entre as marcas/instituições e seus consumidores, trazendo humanidade à relação por meio das mascotes, como coloca Pedro Hellín em sua apresentação à obra.

As mascotes se mostram, na visão da autora, como espelho das construções múltiplas identitárias humanas, que se transferem às formas subjetivas de expressão das marcas. Os multivíduos abordados por Clotilde Perez, a partir da elaboração conceitual de Massimo Canevacci, ganham sua manifestação no universo das marcas, constituindo 
O mundo divertido das Mascotes levado a sério.

de Eneus Trindade

um mundo imaginário que se configura como lugar de estudo da "Semiótica da vida imaginária".

Ademais, cabe destacar que o livro de Clotilde Perez não é interessante só para leitores compromissados com as questões teóricas ligadas ao assunto. Podemos afirmar, com certeza, que a leitura deste livro é um delicioso passeio por um lúdico conjunto de personagens adoráveis, como a Gangue Bardahl, a Galinha Azul da Maggi, o Gênio Habib's, o Homem Azul dos Cotonetes Johnson \& Johnson, o LecTrece (o frango) da Sadia, Os M\&Ms, a Menininha Nhac da Margarina Claybom, O casal Gasolino da Esso, entre outros que compõem o interessante "Mascotário das marcas" que só pela curiosidade em relação à história dessas personagens, justificam a leitura. Fica então registrado o convite para o "contato imediato" com a fantástica "Semiótica da vida imaginária" das mascotes, pois eles auxiliam na compreensão de parte das construções dos mitos de marcas e do consumo contemporâneos. 